\title{
Art Therapy
}

\author{
Warsha Lath
}

Accepted: 30 April 2014/Published online: 3 June 2014

(C) Springer India Pvt. Ltd. 2014

One cold winter afternoon, on December 6, 2012, when I started my art therapy class at NIMHANS, little did I realize that art was just awaiting to spring and blossom in my class of forty.

In the first session itself, I sensed great enthusiasm in my students, who were awaiting me with warm smiles. That put my nervousness at bay and I blessed them in my heart.

My students introduced themselves one by one and I was awed by their disciplined behavior. They were a medley of age groups from all regions of India. After getting to know each other, we were a happier, united group. Here I began my first step by making them meditate deeply and focusing all their concentration on their heart beats and discovering themselves in the silence. To help them in concentrating better, I also sang a soft hymn that I had learnt years ago as a child in my school in Mount Carmel.

After this period of relaxation I requested them to sing. But they were eager to know more about me. So, I told them I was a professional artist, having done a five year course in commercial arts from Sir J.J. School of Arts, Mumbai. Now I am totally involved in my paintings and have had several exhibitions. They expressed a desire to see my works which I showed them later as the classes progressed.

Following this, not much persuasion was required for singing and many of them stood up and sang lilting melodies in their regional languages. It was very interesting to the rest and motivated many others to open up. We discovered it was Anil's birthday too which added to the joy of singing.

Please note that names of all the patients have been changed to maintain their anonymity.

W. Lath $(\bowtie)$

Volunteer at Psychiatric Rehabilitation Services, NIMHANS,

Bangalore, India

e-mail: warshalath@gmail.com

URL: http://www.warshalathart.com
This first session was very important as it set the ball rolling for me. In my regular sessions of art I have taught them songs and hymns (sometimes they express a desire to learn some particular number too), not as much to train them as singers, but to instill confidence and conquer their inner reluctance to mingle with people around them. Needless to say, the group has become a friendlier and pleasant lot, sharing their colours and joking and bonding with each other.

From time immemorial, humans have tried to express themselves - their joys, fears and feelings through art. Right from the cave paintings to the modern day paintings, we have travelled the journey of self- expression. In the first few sessions we had a discussion on art and their perception of it. They were curious to know about the world of paintings and colours. Some knew about artists but for many it was an undiscovered world. Later, they would realize how talented they actually were, just like a bee-hive waiting to be tapped for honey. Their restless minds were like dormant volcanoes.

Nature, according to them was the prime example of art at its best and we concluded these sessions on a happy note that no one could compete with the Supreme Artist. It seemed to make my job easier!

We proceeded diligently transforming the basic shapes into forms, each one defining the shapes into unique ideas. From then on began the sessions of self-expression. Eventually, they got a great opportunity of expressing themselves on various topics for an exhibition in Delhi.

Thereafter, they came up with beautiful works on various topics given to them, e.g.- Happiness, Aspiration, What makes them happy (this was interesting as many drew the artclass in progress, while many others drew nature. Ramesh who is very musically inclined drew a Casio with colourful waves and musical notes arising from the keys. Suresh drew a row of colour pencils in the rainbow colours). Festivals, fruits and flowers have been very popular topics with them. 

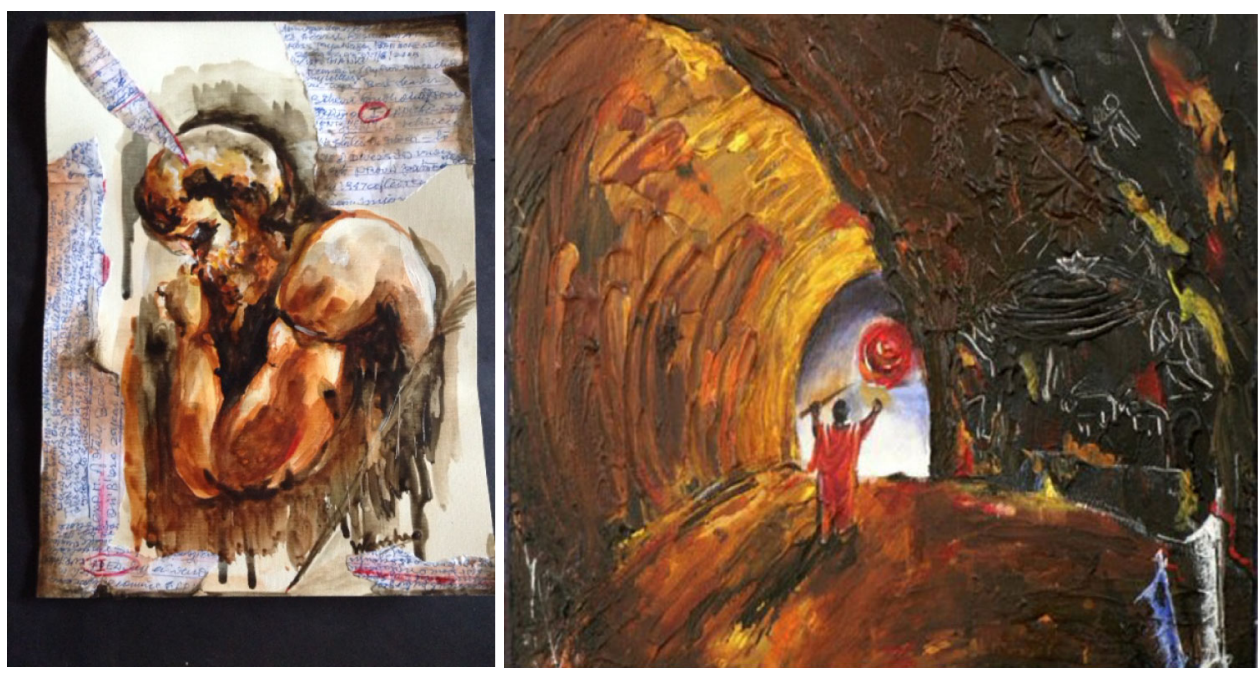

Paintings by Warsha Lath (http://www.warshalathart.com)
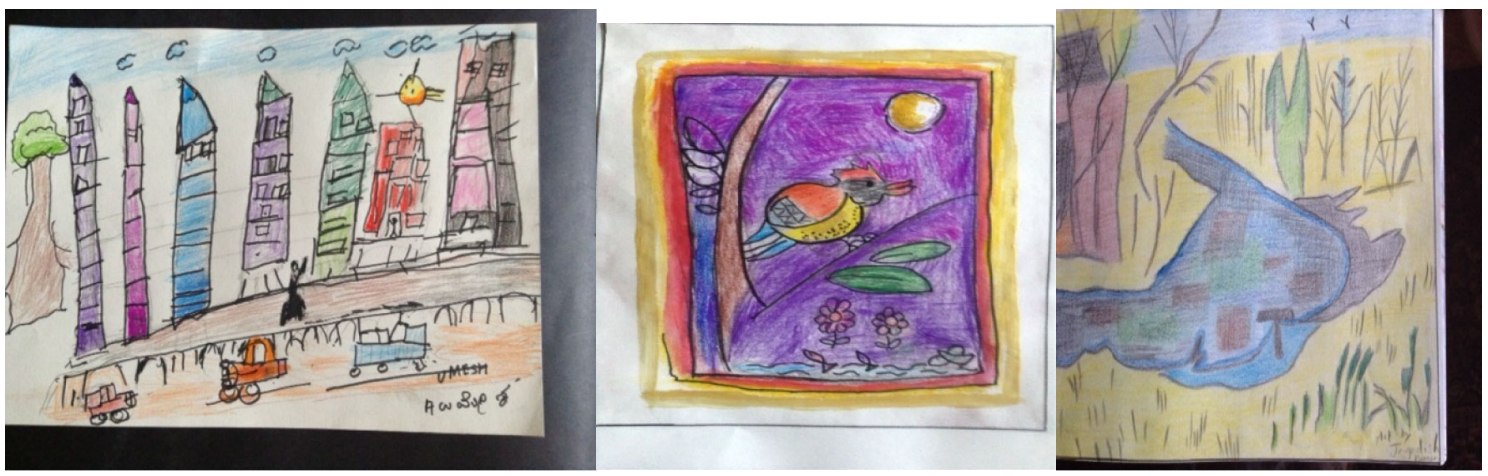

Paintings by the patients

We then moved on to more difficult sessions, to help them improve their skills. For this I showed them some of my paintings to encourage them. In my sessions thereafter I gave them several exercises by making big coloured drawings and paintings of landscapes, fruits, animals, geometric shapes of which smaller drawings in black and white were also made for them to copy and colour.

Freehand drawings with grids for them to copy identically from left to right, were also worked on. Slowly but steadily they were getting more confident about themselves and their talent. Some who were naturally gifted seemed ready to take on the world like Shailesh and Vimal.

Some who had very poor comprehension of drawing and colouring initially, seemed to be injected with infectious creativity now. Ramesh showed creative brilliance in his recent work named 'Pencil Apartments'- his self-expression of the road he takes home, as he walks along the fly-over, imagining all his colour pencils transforming into tall apartments. Once the creative spark is lit, it ignites the mind.

There is spontaneity, innocence and sweet simplicity in their works which make them so appealing. Habib's very simplistic child like drawings, very clear and with minimum colours are as attractive as the brilliant use of colours in Chandra's and Lata's birds (relevant photographs of works to be included here).

Many others have achieved a perfect balance of colours, atmosphere and form, as seen in the calm stance of the girl meditating by Rahul and the train chugging towards you through the valley by Pradeep. Some have a dynamic, forceful use of colourful lines as seen in Ajit, Joshi and Kishore's works which make them impressive.

I showed them the works of Van Gogh and they were mesmerized by his genius which also inspired them, as they are also passionate about their works. Passion which stems from the brain cells. This passion which fills their lives with colours and therefore colours their lives. Colours, forms and finally self-expression which make their lives more meaningful. Happiness and satisfaction glows on their innocent faces when they complete their art-works. I am fortunate that the spark of interest I observed in their eyes the first time, has not died but ignited into a fire. 